\title{
Several Reflections of Dracula: A Case for (Re)Defining and De-centering (Re)Translation[eh1]
}

\section{Dracula'nın Çoklu Yansımaları: Yeniden Çeviriyi Yeniden Tanımlamak ve Merkezinden Uzaklaştırmak Üzerine bir Vaka Çalışması}

\author{
Erdem Hürer ${ }^{1}$ (i)
}

'Boğaziçi University, Faculty of Arts and Sciences, Department of Translation Studies, Istanbul, Turkey

\section{ORCID: E.H. 0000-0002-4944-3457}

Corresponding author: Erdem Hürer (Res. Assist.), Boğaziçi University, Faculty of Arts and Sciences, Department of Translation and Interpreting Studies, Istanbul, Turkey E-mail:erdem.hurer@boun.edu.tr

Submitted: 07.11 .2021

Accepted: 03.01.2022

Citation: Hürer, E. (2021). Several Reflections of Dracula: A Case for (Re)Defining and De-centering (Re)Translation[eh1]. Istanbul Üniversitesi Çeviribilim Dergisi - Istanbul University Journal of Translation Studies, 15, 1-16. https://doi.org/10.26650/iujts.2021.1020259

\section{ABSTRACT}

Postcolonial approaches have brought new insights into translation studies. To date, translation has centered on Western thought and should be decentralized for better understanding. From this perspective, it can also be argued that retranslation requires a new definition. This new definition has been proposed by Şehnaz Tahir-Gürçağlar and Özlem Berk Albachten (2019) in form of "mutability in retranslation," which regards translation not in terms of dichotomies like East or West or as strictly involving word-for-word or sense-for-sense conversion to the target language; rather, it perceives translation as a cluster term. Through the concept of mutability of (re)translation, this article aims to analyze different Turkish (re)translations of the gothic classic Dracula (1897) by Bram Stoker, a well-known Irish author. The novel has been adapted into several films and translated into various languages worldwide. It has also been translated into the Turkish language. However, although there was a Turkish fictional character of a vampire that derived from Stoker's imagery, a complete Turkish translation of Dracula had not existed until 2003, when Niran Elçi's version of the classic was released. Until then, only concealed translations, pseudo-translations, adaptations, illustrations, and other forms of translation had existed in Turkish. This analysis questions these translational acts and attempts to re-define (re) translations of this work. My current findings indicate that although several (re)translations of Stoker's Dracula to Turkish had existed in the past, a proper translation of the text was presented by Niran Elçi in 2003.

Keywords: Translation, retranslation, nezire, te'lif, Dracula, Bram Stoker

\section{öz}

Postkolonyal çeviri yaklaşımları, çevirinin tanımının Batı düşüncesine odaklandığını ve çeviri olgusunun daha iyi anlaşılması için merkezden uzaklaştırılması gerektiğini göstermiş ve konuya yeni bir bakış açısı getirmiştir (Tymoczko, 2014; Trivedi, 2014). Aynı bakış açısıyla yeniden çevirilerin de yeni bir tanıma ihtiyaç duyduğu söylenebilir. Böyle bir iddia Şehnaz Tahir-Gürçağlar ve Özlem Berk Albachten (2019: 1-10) tarafından "yeniden çeviride değişkenlik" (mutability in retranslation) biçiminde ortaya atılmıştır; söz konusu bakış çeviriyi Doğu ya da Batı gibi tekil bir dikotomi üzerinden, kelimesi kelimesine veya anlam 
odaklı şeklinde stratejilerle değil, bir küme terimi olarak görmektedir. Bu makale, tanınmış İrlandalı yazar Bram Stoker tarafından yazılan gotik klasik Dracula'nın (1897) farklı Türkçe yeniden çevirilerini, yeniden çevirinin "değişebilirliği" kavramını akılda tutarak incelemeyi amaçlayacaktır. Roman (ve Dracula karakteri) birçok filme ve diziye uyarlanmıştır ve dünya çapında birçok farklı dile çevrilmiştir. Türk bağlamında da benzer çeviri ve yeniden çeviri eylemleri görülmektedir; "vampir" kurgusal karakteri, Stoker'ın yarattığı imgelerden türetilerek Türk edebi eserlerinde yeniden yaratılmıştır. Ancak 2003 yılına kadar Drakula'nın tam bir Türkçe çevirisi yapılmamıştır. Bunun yerine gizli (concealed) çeviriler, sahte (pseudo) çeviriler, uyarlamalar, illüstrasyonlar ve diğer çeviri biçimleri Türk edebiyat sisteminde yerini almıştır. Çalışmam bu çeviri eylemlerini sorgulayacak ve bu eserin çevirilerini yeniden tanımlamayı amaçlayacaktır. Mevcut bulgularım, Stoker'ın Dracula'sının 2003'te Niran Elçi tarafından "tam" (proper) anlamda tercüme edilmeden önce Türkiye bağlamında birçok farklı (yeniden) tercümesinin yapıldığını göstermektedir.

Anahtar kelimeler: Çeviri, yeniden çeviri, nazire, te'lif, dracula, bram stoker 


\section{Introduction}

Postcolonial approaches to translation brought a new insight into Translation Studies, which indicates that the definition of translation is centered on Western thought, and it should be de-centered to reach a better understanding of the phenomenon (Tymoczko, 2014; Trivedi, 2014). With the same mindset, it can be claimed that retranslations would need a new definition as well. Such a claim is put forward by Tahir-Gürçağlar and Berk-Albachten (2019: 1-10) in the form of "mutability in retranslation", which regards translation not to be a singular term of dichotomies like East or West, word for word, or sense for sense, but as a cluster term (2).

This article aims to analyze different Turkish (re)translations of a gothic classic, Dracula (1897), written by Bram Stoker; a well-known Irish author, with the concept of "mutability" of (re)translation in mind. The novel (and the character of Dracula) has been adapted into lots of films and series and translated in a multitude of languages around the world. The Turkish context shows similar acts of translation and retranslation as well; the fictional character of the vampire is created in Turkish literary works which derived from the imagery created by Stoker. However, it was not until 2003 that a full Turkish translation of Dracula was made. Instead, concealed translations, pseudo-translations, adaptations, illustrations, and other forms of translation took place in the Turkish literary system. The analysis at hand questions these translational acts and attempts to re-define (re)translations of this work.

According to my current findings, it was found that many such (re)translations of Stoker's Dracula occurred in the Turkish literature before it was translated in a "proper" sense by Niran Elçi in 2003. Some examples of those include Ali Rıza Seyfi's Kazıklı Voyvoda (1928), Kerime Nadir's Dehşet Gecesi (1958), or Melek Melih Bayri's Vampirin Kamburu (1974) amongst others. Looking at as many examples as possible, I plan to bring a new look at literary (re)translation; one that does not have a fixed meaning, one that is "mutable". To do so, I conducted an analysis based on the imagery of "Dracula" and the narrative style of the author. I was attentive to the characteristic and visual aspects of the character while also focusing on how some of the stylistic usages of Stoker are utilized by some Turkish author-translators, especially the use of narrative styles.

\section{1. (Re)Defining (Re)Translations}

Tahir-Gürçağlar and Berk-Albachten in their recent work brought about a crucial part of retranslation analysis which was concerned with the definition of translation (2019: 2). They credited names like Tymoczko (2007: 54-106) for defining translation as a "cluster concept", or Koskinen and Paloposki (2010) for bringing together notions of "retranslation, reprint, re-edition, and revision" (Tahir-Gürçağlar and Berk-Albachten, ibid.). Utilizing those works, they established the "mutability" of the retranslation phenomenon.

The work by Tahir Gürçağlar and Berk Albachten includes various case studies, all of which show the mutable nature of both subject matter and methodology of retranslation in the 
Turkish context. It is not possible in a postmodern world to claim that (re)translation is a simple phenomenon which can be explained as "proper" in the understanding of Toury, who suggests that "(prospective) systemic position \& function of a translation determines its appropriate surface realization [which] governs the strategies whereby a target text (or parts thereof) is derived from its original, and hence the relationships which hold them together" (Toury, 2012).

The initial problem here is the notion of original, which is problematized in the Turkish context notably by Saliha Paker (2014). In her article, she argues that the term "original" is not easy to define. "Te'lif", which is associated with the term original in today's Turkey, did not mean the same thing in the past. It meant to translate while adding creative aspects to the original or combining several different source texts, thereby writing a new creative work. Similarly, Paker (2002) and Andrews (2002) suggested that the way translation can be done is not restricted to what translation proper suggests and they both show the example of "nazire" as a means of conducting the act of "terceme".

The Turkish tradition of translation is filled with unorthodox activities such as these, and Paker also suggests that Western history was built on such activity as well (2011: 224-228). Hence it is impossible to state that there is one specifically defined notion of translation and/ or original. While it is not frequently observed in modern days because of royalty issues, such activities do still take place in modern times as well, especially with the older works which are not liable to royalties. Tahir Gürçağlar's article on a translation ("concealed translation" in Tahir Gürçağlar's terms) of Dracula is one such example (Tahir Gürçağlar, 2001). The translation is completed in an almost totally faithful fashion for the first few chapters, and then its context is transported to Turkey rather than England, and nationalist elements are put in the narrative with apparent ideological intentions. Such activity is both representative of the source text and has a creative side in the target culture as well, blurring the line between the acts of writing and translating.

The case of Dracula in that respect is a productive one for it has (according to the data gathered until now) numerous (re)translations that stretch the meaning of the deed. The novel has been used and translated over and over again in the Turkish context without really giving any reference to Bram Stoker. It took 106 years for it to be fully translated in the Turkish literary system, which is awkward when one thinks of its popularity. Both the central position of the novel in its source culture and the popularity it enjoys around the world contradict the situation that occurs in the Turkish context.

\section{Studies on Dracula and Bram Stoker}

Dracula (1897) is a gothic classic written by Bram Stoker, a well-known Irish author. It is accounted as the best novel of Stoker by many (D'Ammassa, 2006; Lovecraft, 1973; Horgen, 2012). In fact, in Don D'Ammassa's Encyclopedia of Fantasy and Horror Fiction (2006), the author is introduced with: "Bram Stoker is, of course, best known as the author of DRACULA 
(1897), which defined the vampire for modern horror fiction and whose central figure has probably appeared in more motion pictures than any other fictional character..." It is seen in this quotation that Stoker's character inspired many others to write similar characters in their novels or scripts as well. However, those authors (and sometimes translators in this case) are observed not to take all the aspects of the iconic image of Dracula but they seem to blend it into their own cultural norms. (Seyfi, 1928; Nadir, 1958; Bayri, 1974)

While Stoker's work with Dracula is considered today as one of the best examples of gothic literature, Bram Stoker as an author himself was not considered to be that well-versed at the time he was writing. In the book called The Lost Journal of Bram Stoker: The Dublin Years (2012: 217-218), Elizabeth Miller and Dacre Stoker state that Bram Stoker was not so popular as an author even with a work like Dracula, and this is also stated by Lai-Ming Ho in her Ph.D. thesis (2012). Coming from his great-grandnephew, this is an important comment, especially considering Dacre Stoker's several other works on Dracula which could be seen as its sequels. Still, his research on Dracula show that even if Stoker's other works were not as forceful in the literary field, his one shining material still was a great one to be studied. This is backed up by many a thesis which was written on Dracula, the fields of which range from literature to sociology and anthropology (Ho, 2012; Hughes, 1993; Moore, 2010).

There are two theses that have been published, on Stoker's Dracula in Turkey (Bayan, 2011; Özlü, 2004), andone of them focuses on the work's place in the literature while the other one looks at the film adaptations of the work and makes an analysis of them in a mythological manner; and few pieces of research have been made on the Turkish translations of Dracula (Karagöz, 2012; Tahir-Gürçağlar, 2001 \& 2008).

Although these studies stated above were made, there is no analysis of Dracula regarding its (re)translation in Turkey. Tahir-Gürçağlar, whose analyses are the most descriptive and are related to the translations of Stoker, speaks of two works in separate studies. In the article she wrote for Target (2001), she describes the birth of a nationalist literature through translations using Kazlkl Voyvoda as a case, and in her work The Politics and Poetics of Translation in Turkey, 1923-1960 (2008), she describes the translation of Drakyola: Kan İçen Adam while speaking of Selami Münir Yurdatap as a productive individual for his translations.

Selahattin Karagöz (2012), on the other hand, speaks of the works named Kazıklı Voyvoda (Seyfi, 1930) and Dehşet Gecesi (Nadir, 1958) in his MA thesis; however, he speaks of Ali Riza Seyfi as an author while Seyfi's work was already declared a "concealed translation" by TahirGürçağlar (2001). Besides, even though he speaks of Dehşet Gecesi and calls it an adaptation (which is a questionable definition), he does not give further information on this book regarding its relation to Translation Studies. Of course, his work was not on Bram Stoker or Dracula per se; he was describing the repertoire regarding his study on Howard Phillips Lovecraft and the translation of horror fiction. These being said, it is clear that there is a gap in the analysis of Stoker's work considering the novel's (re)translations in the Turkish literary system. 


\section{Bram Stoker's Dracula}

The work of Stoker was not the first time the world had ever got to know the image of the vampire, though it might be the most effective one in history. Count Dracula was both the epiphany of evil and awkward. In the work, the character is observed for the first four chapters through the keen eyes of Jonathan Harker, whose description of Dracula will be used to define the imagery of the character.

Dracula is a strong figure according to his looks. He is a tall and thin man at first glance; also, he seems noble, which he is. His white hair and white mustache covering his mouth are some of the aspects that Harker pays much attention to, in addition to his thin nose, his massive eyebrows, and his pointy, pale ears. His livelihood and cruelty are seen through his mouth which was red with shining white sharp teeth. (Stoker, 2012: 20) His personality seems to be unbalanced and mysterious. He initially seems to be a courtly gentleman with fluent English which is not his native language. These aspects indicate that he is a novelty and he is an intelligent person. His glare hides his cunning side, while sometimes this turns to rage and fury. He is a man to be respected and not to be angered.

His traits are not limited to his figure and personality of course. He is a master of disguise as can be seen from his bearded image as a driver and his disguise as Harker himself. He is capable of controlling wolves, which can be observed when he sent them away from the coach and when he summoned them at will, either when he called them to eat the lady at the gate or to scare Harker to stay in the castle. He can scale the walls of the castle, and he uses this ability to get in and out of his room from his window. He has no reflection in mirrors and apparently, he dislikes them as he throws Harker's mirror out through the window. He is also able to vanish in thin air and appear from out of nowhere. He sleeps in his coffin in the daytime when everyone else is awake. He can regenerate his youth by virtue of the blood he drinks from his victims. (Stoker, 2012: 1-61) These aspects aside, he also can turn into a large bat, or a wolf as is observed on several occasions in the book (krş. Stoker, 2012: 108, 126).

These aspects of Dracula are what make the character so iconic. In all of his depictions, there are at least some of these aspects which help the character to be identified. In that, the analysis at hand will be looking at different literary and cinematic narratives that either clearly or obliquely use the same kinds of characters depicted in them. For that matter, Kazlkll Voyvoda/ Dracula İstanbul'da (1928/1946/1997), Drakyola: Kan İçen Adam (1940), Drakula İstanbul'da the film (1953), Dehşet Gecesi (1958), Seksomanyak (1974), and Vampirin Kamburu (1974) will be observed given the relationship with the image of Dracula.

\section{Turkish (Re)Translations of Dracula Between 1923-2003}

\section{a. Ali Rıza Seyfi's Kazıklı Voyvoda (or Drakula Ístanbul'da)}

Ali Riza Seyfi's Kazlkl Voyvoda/Drakula İstanbul'da (1928/ 1946/ 1997) was defined as a concealed translation by Tahir-Gürçağlar as can be seen above. Tahir-Gürçağlar grounds her 
definition on Toury's identification of translation, which constitutes three postulates that she does not mention but does use in her analysis. These postulates are "the source text postulate", "the transfer postulate", and "the relationship postulate". (Toury, 1995: 33) The source text postulate is established with the acknowledgment of Stoker's Dracula as the source of Ali Riza Seyfi's work. The transfer postulate is observed through the macro-textual analysis (on the genre of the text) that Tahir-Gürçağlar constructs, and the relationship postulate is observed through the micro-textual analysis (on the specific additions and omissions throughout the text). These postulates though do not apply to the paper at hand as the translational act doesn't need to take place in the target text thoroughly.

Ali Riza Seyfi first published his work Kazıkl Voyvoda in 1928, just five years after the Turkish Republic was formed. As the year of the publication of the book and the reformation of the Turkish alphabet co-occurred this year, it is understandable that the text was written using the Arabic alphabet (in 1946, it was re-published in the Latin alphabet). However, the text was also written with strong nationalistic messages, which are seen in almost every addition made by Seyfi to the source novel. The characters, except for Count Dracula (whose name was only phonetically transformed to Drakula), were all given a Turkish name; and the context was taken from London to İstanbul.

Still, almost all the mainframe was kept as it was, except for the last part which was made briefer by omitting the last part of Harker's Journal. Many other omissions were made which could be observed through Tahir-Gürçağlar's work too; however, the main point of this paper is not the work as a whole but how the image of Dracula was shown. It can be said that Seyfi had a faithful strategy and translated almost all of the character's visual and characteristic aspects as they were.

The difference is seen in the imagery of the antagonist. In the source text, Dracula was not the enemy of England as a whole but the enemy of the people whom he had a direct effect on. In Seyfi's work, on the other hand, it is observable that the antagonist is not just related to the protagonists but to the whole Turkish nation. This is relatable to the era that Seyfi was writing in. As Tahir-Gürçağlar mentions in her work (2001), this was an era in which the national identity of the Turkish people was being rebuilt. One of the best ways to create a national unity is to create an enemy that the whole nation can unite against; Seyfi uses the character Kazıklı Voyvoda for that; knowing that in history Vlad the Impaler killed lots of Turkish soldiers.

Since no other novel can be considered as being related to either the character or the novel Dracula, Kazlklı Voyvoda can be considered as the initial translation of Dracula. Antoine Berman's so-called retranslation hypothesis and his views on initial translations of translated works seem to hold up for this novel; Kazıklı Voyvoda extremely domesticates the source text. While it is true that all the physical aspects of Dracula are kept as they were in the source text, the religious items were changed from Christian items to Muslim ones, getting rid of the cross and using "enam" (Seyfi, 1997: 46), a Muslim talisman in which there are verses of the Koran instead. The Turkish nation element takes a whole lot more space in the target text 
while it was only cited in the source text. As mentioned above, even the names of characters were changed into Turkish ones; "Jonathan Harker" was turned into "Azmi Bey" for instance. The context of the novel starts from Transylvania at first which is in line with the source text, however, it then returns to Istanbul, Turkey; rather than going to London, England as it does in the source text. All these changes indicate that while there is a translational act in Ali Riza Seyfi's novel, the work is creative in itself, making it closer to what Paker calls "telif" (Paker, 2013) than a translation proper.

\section{b. Selami Münir Yurdatap's Drakyola: Kan İçen Adam}

Because of the difficulties encountered while trying to access this material, this analysis will be made from secondary sources written by Tahir-Gürçağlar (2008: 205-212) and Oğuz Eren (2012: 10-18). While Tahir-Gürçağlar stays skeptical of the relationship between this work and Bela Lugosi's film Drakyola Kan İçen Adam (1931), Eren (2012) defines the text as a film-novel written for people who could not watch it in the cinema because of financial issues (still as Tahir-Gürçağlar states, whether the book precedes the film or not is obscured, as the date in which the film was released in Turkey is uncertain).

The book has a certain relation to the source material Dracula though. The name of Stoker was mentioned by Yurdatap and he claims it is a full translation, though the work was abbreviated to 16 pages; which bears an unorthodox notion of translation. The name of the translated work mentions the name of the main antagonist "Drakyola", though it is changed according to the Turkish phonetics of the time. Still, not much of the characteristics of Drakyola is mentioned in Tahir-Gürçağlar's work (2008: 205-212), she mentions the part where Harker states "Count Dracula, the blood-drinking monster has arrived in England. Nobody knows his mystery but me. The country must be saved from his evil and murders" (Stoker, 1940). The quote shows some important information along with the paratextual elements of the translation.

First of all, the translator is accustomed to the author of the source text, and the novel. Secondly, the character Dracula does not go to Istanbul but rather he goes to England which indicates that Ali Riza Seyfi's translation did not have a huge influence on Yurdatap; there is not much intertextuality between the two translations. Bela Lugosi's film Drakyola Kan İçen Adam (1931); however, seems to have affected the name of Yurdatap's translation directly. As there is the name of Stoker as the author of the book, and as Yurdatap defines himself as a translator and the novel as a full translation; the text needs to be considered as the first retranslation of the novel in the Turkish context.

\section{c. Drakula Ístanbul'da (the Film)}

Drakula İstanbul'da was a film by Mehmet Muhtar (1953), and its script was developed from the work of Seyfi's novel/translation; Kazıkl Voyvoda (1946). From the analysis made on both works, it is understood that there is almost a word for word-level similarity between 
the two; even the omitted parts of Stoker's work were available for observation. The film was created in such an era that Scognamillo and many others defined as "the miserable era of Yeşilçam” (cf. Scognamillo, 2011), in which a great number of adaptations were made from foreign narratives in Turkish cinema and no source was mentioned; and this was one of them.

The character of Dracula was kept as Seyfi's description which also fitted the one created by Stoker; despite having the nationalistic touch to show him as a nation's enemy. Phillip Madden, in an article given to Hürriyet Daily, speaks of the work with ironically great praise, stating:

"Dracula in Istanbul" is arguably the most complete film in its fidelity to the Bram Stoker novel up until this time. Dracula hypnotizes his victims, and they cannot resist his magnetic charisma. There is also a chilling rendition of the baby-in-the-bag scene in which the vampire throws down a bag to one of his female cohorts only for it to start kicking and writhing, implying a small child is inside. No filmmaker had been brave to do that before, not until Coppola's 1992 version of the novel. ${ }^{1}$

Muhtar's work depicted Dracula as a character as well as it could have in a culture that does not seem to fit because of differences in basic aspects such as religion, morals, and so on. Still, some differences are visible from the source text (if we consider Bram Stoker's Dracula as such) as it was adapted to film from the novel of Seyfi, rather than the novel of Stoker. Thus, the definition of this adaptation needs to differ from others; it is a re-edition of a "concealed translation", or rather a "telif" and it is therefore, in terms of Kaisa Koskinen and Aoti Paloposki (2010) a form of retranslation.

\section{Kerime Nadir's “Dehşet Gecesi”}

Nadir's Dehşet Gecesi is another depiction of Dracula that seems to fit its era of creation. It was written by an author whose other works are considered to be in the genre of romance. It was published in 1958 when erotic narratives were at their peak in popularity. Hence, the work is fitting to its context, as there are quite many occasions where the main antagonist was flirting and seducing men. There are even some scenes of extreme sexuality in the novel.

The main antagonist is named "Princess Ruzihayal"; this character is the counterpart of Dracula in the novel. The biggest change as can be seen through this shift is the sex of the character. Princess Ruzihayal is the late aunt of Selmin, the soon-to-be bride of one of the main protagonists Cengiz. The story gets its first sensation of Dracula from the way it is told as there is a book, much like Harker's journal, which tells the story of Cengiz; a man who is summoned to a mansion in the middle of nowhere by a mysterious person as a representative. The mansion, as Count Dracula's castle, is right next to a cliff dropping far below and is inside a faraway city, in which Cengiz is considered to be an alien. Cengiz gets to Hakkari and tries to get to an inn from which he is to be picked up by the private cart of the princess. He is warned

1 The article was in publication in May 20th, 2017 at http://www.hurriyetdailynews.com/dracula-in-istanbul. aspx?pageID $=438 \& n=$ dracula-in-istanbul-2003-11-05 but today it cannot be directly accessed. 
against going to such a place by the local people as some dangers are awaiting him. He goes anyway and faces the demons, in the end destroying them with the power of "enam-1 şerif"; which is linked intertextually, as Eren (2012: 11) also points out, with the initial translation of Ali Riza Seyfi (Nadir, 1958: 13-107). As is customary for the ends of almost all fictional novels of the era, an educative message is given by Nadir too: "all these things that happened to me were the punishment of mine; as I did not do with less and pursued millions. Men should never dream of the magnificent" (Nadir, 1958: 107).

The mainframe of the sub-story is quite like Dracula, as can be seen from the short description above. The story from there on continues with fictional writing of what came to be of Mümtaz who was going to the same destination. It is observed that Mümtaz, much like Cengiz goes through hell, and just as he is about to become a "ghoul" he wakes up understanding he was in a train accident and hit his head too hard somewhere (Nadir, 1958: 159-160). This logical explanation may have been given because the Turkish people were not very well accustomed to the fantasy fiction genre, and they needed to be brought back to reality at some point by the author. This is not the only time that the audience is told that the story is fictional, the author describes the genre as fantasy fiction at the beginning of the book in addition to the imagery inside the sub-story (1958: 10-11).

Coming back to the main antagonist, it is safe to assume that the character partly originates from Dracula himself and partly from the vampiresses from Dracula. The character in Nadir's work is referred to as a witch and a ghoul and shows aspects of the creature "lamia" from the Greek myths; however, calling her "vampiress" would be more befitting as the storyline originates from a vampire story. Her aspects show equivalence with the character Dracula, having crimson lips with sharp white teeth, being courteous, and having skin that both makes one tingleand disgusts at the same time. Besides, she is much like the vampiresses in Dracula, wanting to kiss their prey (bite and suck their blood) and seducing men to do their will. Still, more like Dracula, she has authority over the ones she previously turned into her pawns, and she can shapeshift into an owl just like Dracula can shift into a bat shape. She is afraid of God's word and symbols, and just like Dracula is afraid of the cross. She gains youth through the blood of her prey and becomes beautiful when she feeds. Lastly, she needs to be stabbed through her heart into the ground she lays in the day, and some mirror dust is to be poured on her to make sure she stays dead. She is not fond of mirrors as they show her true shape, just like Dracula not having an image on them and doesn't allow the protagonist to have any mirror in her mansion.

As can be seen through the description of Ruzihayal, she is the representation of Dracula in Turkish culture at a time in which erotic and sexual narratives and films were at their peak. In this era, many films were produced that included nudity or some sex scenes to attract audiences. Also, there was a movement of publishing popular literature in the era, with financial benefits in mind, which was conducted on a vast scale by private publishing houses (see. Tahir- 
Gürçağlar, 2006). These clues might indicate that Dehşet Gecesi is a retranslation of Dracula into Turkish, however here the definition of translation again fits more to "terceme" or "telif" than translation proper, as the author of Dehşet Gecesi takes the narrative forms and some characteristic aspects of a source material and transforms them into a new creative product.

\section{Seksomanyak}

The increasing erotic vibes of the era between the ' $60 \mathrm{~s}$ and " $70 \mathrm{~s}$ led the way to a more sexually driven vampire imagery. In these circumstances, the photonovel Seksomanyak was created by Yener Çakmak (1974). Only eleven published issues were found of this photo novel, and they present enough imagery to relate it with Dracula. Yener is pictured as a normal man in 1970's Istanbul. He is a boss in an unspecified corporation. He is, underneath, a vampire that sucks the blood of beautiful women. ${ }^{2}$

Yener while in the shape of a vampire becomes a sociopath: his eyes become darker, his teeth grow and become sharper, to bite the victims' necks and suck their blood. He is ever vengeful and furious. He is cunning as well and a master of disguise which is understood from how easily he approaches his victims. While he is in his daily disguise as a boss though, he acts as a normal, cool man and does not attract attention. He is a gentleman that is desired by many women. Thus, he presents lots of similarities with Stoker's Dracula, though a direct inspiration is not mentioned over the character.

One of the most unorthodox examples of adaption/(re)translation can be shown through this depiction of the vampire. The basic aspects of Dracula are again transferred to the antagonist of the work, but this time the medium is changed. This change brings visual aid into the textual narrative and creates a new kind of resemblance between the source text and the target text. While it is not a full translation of the novel Dracula, there is no doubt that the character is transferred into the narrative of the photo novel; thereby creating a pseudo-(re)translation of the work.

\section{Vampirin Kamburu}

Vampirin Kamburu was written by Melek Melih Bayri in 1974. The work is a crime fiction novel telling its tale from the first-person point of view. With the popularity that crime fiction gathered after the republished Cingöz Recai novels of Peyami Safa in $1962^{3}$, there followed several crime fiction writings. This particular one has a twist in it though, as it has both the aspects of psychological thriller and fantasy fiction.

At the beginning of the novel, the reader quickly gets to know the insight of the main character who is quite akin to the Nosferatu imagery of Dracula. Nosferatu was a German film that was sued for plagiarism from Stoker's work Dracula. Still, making many changes in

2 The photonovel is last accessed on January 5th, 2020 from: http://www.ucuztarih.com/foto-roman/seksomanyakfotoroman/.

3 These novels themselves are derived from Maurice Leblanc's Arsene Lupin. 
the plot and the main character, it created its name Nosferatu and made itself seen throughout the world. The main antagonist in the film is a bald man with cavernous eyes, sharp teeth, sharp and long nails, a crooked nose, and a hunchback; the thing might be called ugly when compared to Dracula.

The name of Bayri's novel can be translated as "the vampire's hunchback". At the beginning of the work the reader gets to know Ergün, the main antagonist of the novel. The man defines himself as a cold-blooded being with sharp teeth, a hunchback, and bulging eyes; and he is afraid to look at mirrors (Bayri, 1974: 10-11). While the imagery seems to come from the depiction of Nosferatu, the intertextuality starts from Dracula hence a claim for this to be a retranslation in the form of "telif" is possible.

The antagonist of Bayri is also obsessed with blood, and he craves it. He states, "when it was night, in my lonesome chamber, the scents of fresh blood came to my nose. [...] Blood... Oh, what a lovely color"4 (Bayri, 1974: 74). And what is even more important is that after he has had his blood his looks begin to change: "When I came to my flat I felt peaceful. My eyes caught sight of the mirror. I got twenty years younger. I had a sweetish taste in my mouth. When I took a closer look at myself in the mirror, I noticed that there were bloodstains on and around my lips" (Bayri, 1974: 187). As can be seen from the excerpts, drinking blood made the antagonist younger. This was explained by Bayri to be a sign of mental disorder though; it is stated by another character that the man was a young and attractive person who spoke gentlemanly and was sophisticated, all of which are the defining aspects of Dracula in his noble form.

\section{Historical Analysis of the Hypothetical Retranslations of the Character Dracula in Turkish Culture}

As can be seen above, there are a number of narrations regarding the character of the vampire in Turkish culture. Under this sub-heading, an analysis will be made over the above-described hypothetical retranslations, going through them in a hierarchy of the date of publishing (from older to newer). In doing so, the final and probably the most crucial part of this article will be covered, as these narrations will be analyzed with the issue of changing norms and changing narrative styles in mind.

The norms of the era considering literature played an important role in the creation of each translation. The initial translation Kazlklı Voyvoda is one of the best examples of that. After the Turkish War of Liberation, the Turkish Republic was formed in the year 1923. This date not only holds a national value in itself for Turkey, but it was also a "turning point" for Turkish literature. With a new governmental system in force, people were trying to get used to the new way of living and they were trying to learn about their liberties. They were also brought together under the discourse of "nationalism", one of the core principles of Atatürk. Under these circumstances, it was quite understandable that literature played its role of being

4 Translations are mine unless otherwise stated. 
a teacher to this newly found country. Hence translations played a huge role as well.

Ali Riza Seyfi in this era created a "concealed" translation of the work Dracula and deemed himself the author of the novel. This was not the only change he made on the text, though. He also added a nationalistic view on the narrative and created a monster for the people of his nation that they can, as a whole, fight against (just as they did five years ago in the War of Liberty). These claims can be backed up by Seyfi himself looking at an interview he gave to Mehmet Berk Yaltırık:

As a mariner who knew English in the era of National Struggle, while I was working in the translation bureau in Ankara, I got accustomed to some works of English literature. When I saw Vlad the Impaler, who was a historical enemy of ours in the work Drakula, I aimed to narrate him as who he really was in my work (Yaltırık, 2012: 20)

Drakyola: Kan Içen Adam, on the other hand, did not hold such a stance, as far as it can be observed through Tahir-Gürçağlar's analysis on the book. The reason for that was probably the creation of the translation bureau, which aimed to create a canon in Turkish literature through the use of the translation of western classics. This was approximately the years between 1940s and 1960s, and between these years 947 texts were translated into Turkish (Tahir-Gürçağlar, 2006: 577) which shows that Turkish people were accustomed to the translations of western literature; thereby allowing Yurdatap to create a legitimate translation, calling himself a translator rather than the author. Still, though, the work was abridged to 16 pages from Stoker's 420 pages, which is probably because of the medium of Yurdatap's published works, and the novel being translated looking at the depiction of Bela Lugosi's Drakyola Kan İçen Adam. In the same interview that was held with Seyfi, Kerime Nadir was present and was speaking of her work Dehşet Gecesi. Her statement for the work was as follows:

I was also inspired by the work Dracula for my narration. I did it knowing that it was not a popular thing and I did it willingly. I have narrated horrifying hearsay, which was a part of an unrecognized and unknown culture. My former works were discussed and I was criticized for not giving any informative ideas to the reader. I saw literature not as a purpose of teaching but as a reading experience. (Yaltır1k, 2012: 20)

In Dehşet Gecesi, the shift that the character goes through is relatable to the information given above by Nadir herself. The character of Dracula was changed into an image of a vampiress, and the female antagonist was repeatedly trying to seduce the protagonist with her charming looks. The character was a "repulsive" character for the time, however, the era that followed proved otherwise. The work was created in 1958 which was again a turning point for Turkish literature, as the translation bureau created by Hasan Ali Yücel was coming to its end. From there on, the private publishing houses were to gain huge popularity and erotic narratives were a part of the change which can be seen most concretely in Turkish cinema.

Of course, naming Dehşet Gecesi as the changing factor in such a movement would be claiming too much, although what followed the work was interesting to observe. The next vampire figure seen 
in Turkish literature was Seksomanyak (1970) which was a photo novel. In this example, observing the main antagonist is much easier considering the visual aids in the text itself. The imagery of the vampire was almost hand in hand with the western vampire; he had sharp white teeth hanging from his mouth, he had dark eyes, a sinister look, and besides this, he had a tendency to suck the blood out of women and kill them which is quite relatable with the imagery of Dracula.

These years were the peak of pornographic and erotic films; thus, the photo novel was showing huge relevance to the norms of the era. Also, the concreteness of the character was eye-opening, as in the same years, films like Seytan (which is an adaptation of another film called The Exorcist), and Süt Kardeşler (which had the image of "Gulyabani", a fictional demon-like creature) were being made. So, the horrifying, fictional, and concrete figures were being experimented with on the big screen. In such an era, the image of the vampire also found its place in the system.

In 1974, four years after Seksomanyak, Bayri's Vampirin Kamburu was published. This work was most probably inspired again by Dracula; however -from the narration of the antagonistit is observable that Bayri was using the film Nosferatu as her guiding light. Bayri in Eren's article (2012) is stated to be a writer, who had been dabbling with the issue of morals in her other works. In addition to the creation of the image of Nosferatu, moral issues are observable; and the work can be classified as a psychological horror,thriller novel, or as a detective novel.

Again, in the era, there were many detective novels and films at hand. This can be backed up by the work of Erol Üyepazarc1 titled Korkmayınız Mister Sherlock Holmes (2008). Between the years 1971 and 1972 alone, there were 19 separate translations of the famous detective novels of Maurice Leblanc with the character called Arsene Lupin. These were published by three different publishing houses. (Üyepazarc1, 2008: 626-627) In addition to this, films of the era could support this claim as well. Olcay Holat in his MA Thesis (2015) makes a historical analysis of the detective films made in Yeşilçam and states that names like Ayhan Işık, Cüneyt Arkın, and Yılmaz Güney helped the detective films of the ' 70 s to shine. It is also inferred that the 70's era was the most productive time for detective films in Yeşilçam (Holat, 2015: 105-106).

\section{Conclusion}

With all the description both of the depiction of Dracula in different texts and of the eras in which these depictions took place, it is fitting maybe to label Ali Rıza Seyfi, Selami Münir Yurdatap, Kerime Nadir, and Melek Melih Bayri as author-translators much like the poettranslators of the Ottoman era (see. Paker, 2002). These author-translators were on one side trying to fill a gap in the Turkish literary system, and on the other, they were creating novels that were in line with the mainstream forms in the literature.

The main struggle was caused by the ideological style of the time and place. They were creating a new genre which was a fictional one, in an era of humanism and social realism 
for the Turkish literary system. This fact is brought forward by Nadir (Yaltırık, 2012: 21) as well as Seyfi, who stresses; "In the 1920s, we created a new order [rooted in social realism], and of course, we were going to back it up with literature. This is why Kazıklı Voyvoda [...] was written so [...] It was fantastic in the core, but I never had the urge to create fantastic narratives" (Yaltırık, 2012: 21).

These are some of the reasons why the novel Dracula was not translated to Turkish in full for over a hundred years. Still, however, the best reason for the translations to occur as concealed/pseudo/abridged versions is systemically given by Hüseyin Rahmi Gürpınar: "The creation of gothic literature corresponds to the time we acknowledged the western literature. At the time gothic literature was not even accepted by the west and it was viewed as cheap product" (Yaltırık, 2012: 22). Gothic literature was at the periphery when Dracula was written, and the Turkish literary system was showing interest in what was at the center of the western literary system. Then it is no wonder that Dracula was not translated right away; it waited for three decades just to be recognized by the Turkish translators, and even then, it got stuck in the realism of the era and was not translated in full. Still, it is obvious that Dracula's retranslation journey did not start in 2003; the mutability of translation is hence shown, as lots of different forms of the translation act were carried out on the work by what I call author-translators, and they, in the end, made it possible for the Turkish literary world to get over the hump of realism, opening the way for Turkish and translated fantasy/ gothic fiction to be published.

Peer-review: Externally peer-reviewed.

Conflict of Interest: The author has no conflict of interest to declare.

Grant Support: The author declared that this study has received no financial support.

\section{REFERENCES}

Andrews, Walter G. (2002) "Starting Over Again: Some Suggestions for Rethinking Ottoman Divan Poetry in the Context of Translation and Transmission." In Translations: (Re)shaping of Literature and Culture, edited by Saliha Paker, 15-40. Istanbul: Boğaziçi University Press.

Bayri, M. Melih. (1974). Vampirin Kamburu. Ankara: Bayraktar Yayınevi.

Berman, Antoine. 'La retraduction comme espace de la traduction', Palimpsestes, 4, p. 1-8, 1990.

D’Ammassa, D. (2006). Encyclopedia of Fantasy and Horror Fiction. New York: Infobase Publishing.

Eren, O. (2012) Fantastik Alaturka. Gölge. 58 (July) URL: https://issuu.com/golgedergi/docs/golge_e-dergi_ fantastik_dosya_temmuz_2012_sayi_58. Son erişim:

Horgen, S. (2012). Writing the National Self: Bram Stoker's Dracula and Anglo-Irish Gothic Identities. England: University of Kent.

Koskinen, K. \& Outi Paloposki (2010) Retranslation. Handbook of Translation Studies. v. 1, pp. 294-298.

Nadir, K. (1958) Dehşet gecesi. İstanbul: İnkılap ve Aka. 
Paker, S. (2011) Translation, the Pursuit of Inventiveness and Ottoman Poetics: A Systemic Approach. Between Cultures and Texts: Itineraries in Translation History. Antoine Chalvin, Anne Lange, Daniele Monticelli (eds). Frankfurt: Peter Lang. p. 223-234.

Paker, S. (2014). Terceme, Telif ve Özgünlük Meselesi: Eski Türk Edebiyatı Çalışmaları IX. Metnin Halleri: Osmanlida Telif, Terceme ve Şerh. İstanbul: Klasik Yayınları.

Sarpkaya, S. (2016) “Türk Kültüründe Vampir: Türk Dünyası Anlatıları ve İnançlarından Hareketle Türk Kültüründe Kan İçen Olağanüstü Varlıklar” III. Genç Akademisyenler Sempozyumu Bildiriler Kitabı. Ankara: Gazi Üniversitesi, pp. 538-615.

Seyfi, A. Rıza (1928) Kazıklı Voyvoda. İstanbul: Resimli Ay Matbaası.

Seyfi, A. Rıza (1946) Kazıklı Voyvoda. İstanbul: Çağır Kitabevi.

Seyfi, A. Rıza (1997) Drakula İstanbul'da. İstanbul: Kamer Yayınları.

Stoker, B. (1897/2012). Dracula. London: Penguin.

Stoker, B. (2003) Drakula. Niran Elçi (trans.). İstanbul: İthaki Yayınları.

Tahir-Gürçağlar, Ş. (2001). Adding towards a nationalist text: On a Turkish translation of Dracula. Target. 13(1). pp. 125-148.

Tahir-Gürçağlar, Ş. (2006) “Tercüme Bürosu ve Bir Edebiyat Kanonunun Oluşturulması”, Talat Sait Halman (edt.) Türk Edebiyatı Tarihi 4, İstanbul: TC Kültür ve Turizm Bakanlığı Yayınları, 571-586.

Tahir-Gürçağlar, Ş. (2008). The Politics and Poetics of Translation in Turkey, 1923-1960. Leiden, The Netherlands: Brill | Rodopi. doi: https://doi.org/10.1163/9789401205306

Tahir-Gürçağlar, Ş. \& Özlem Berk Albachten (ed.). (2019). Studies from a Retranslation Culture: The Turkish Context. Singapore: Springer.

Trivedi, H. (2014). In Our Own Time, On Our Own Terms: ‘Translation’ in India.

Translating Others. Theo Hermans (Ed.). New York, NY: Routledge. 102-119.

Tymoczko, M. (2014) "Reconceptualizing Translation Theory: Integrating Non-

Western Thought about Translation," Translating Others, Theo Hermans (Ed.), New York,

NY: Routledge, p. 13-32.

Yaltırık, Mehmet B. (2012) Kerime Nadir, Ali Rıza Seyfi ve Hüseyin Rahmi Gürpınar ile "Fantastik Türk Edebiyatı" üzerine bir mülakat. Gölge. Vol. 58, pp. 19-23. 